\title{
TRIP 型複合組織鋼の深絞り性に及ぼす炭素添加量の影響
}

\author{
長坂 明彦* ・杉本 公一 $* 2 \cdot$ 小林 光征 ${ }^{* 2} \cdot$ 小林 義一* - 橋本 俊一 $* 3$
}

Effect of Carbon Content on Deep Drawability of TRIP-aided Dual-phase Sheet Steels

Akihiko Nagasaka, Koh-ichi Sugimoto, Mitsuyuki Kobayashi, Yoshikazu KobaYashi and Shun-ichi Hashimoto

Synopsis : Effect of retained austenite on the deep drawing in high strength TRIP-aided dual-phase (TDP) sheet steels with different carbon content were investigated. The deep drawability based on the limiting drawing ratio $\left(L D R=D_{0} / d_{p}\right)$, where the $D_{0}$ and the $d_{p}$ are a maximum blank diameter and a punch diameter respectively, was affected by the volume fraction of the retained austenite and by its stability (carbon concentration). Namely, the higher the volume fraction of the retained austenite and its stability, the larger strength-deep drawability balance, i.e., the product of tensile strength and $L D R$. Furthermore, the higher blank folding force, the larger the strength-deep drawability balance of high carbon TDP steel. The excellent deep drawability was due to large local necking resistance at the cup wall just above the punch bottom due to "the transformation hardening" and "the stress relaxation" resulting from the strain-induced martensite transformation, as well as a low drawing resistance of the shrinking flange.

Key words: deep drawability; retained austenite; transformation-induced plasticity; strain-induced transformation; dual-phase steel; high-strength steel; blank holding force.

\section{1. 緒言}

近年，環境問題に対応すべく乗用車の車体軽量化と衝突 安全性向上を目的に開発された高強度鋼板の中で, 残留 オーステナイト $\left(\gamma_{R}\right)$ の変態誘起塑性(TRIP $)^{1)}$ を有効に利用し たTRIP型複合組織鋼 ${ }^{2-14)}$ (TDP鋼) はとくに優れたプレス 成形性を有する。すでに，590 MPa 級熱延TRIP鋼板がフ ロントサイドメンバなどの衝撃吸収部品やロアアームなど の足回り部品に一部実用化されている ${ }^{15)}$ 。今後の展開とし ては, 高強度鋼板の難成形部品への適用拡大やテーラード ブランク ${ }^{16)}$ による材料置換などにより, 乗用車の車体軽量 化と衝突安全性においても，さらに大きな役割を担ってい くものと期待される。

TDP 鋼は深絞り性 ${ }^{11-14)} も$ 優れているが，この深絞り性に 影響を及ぼすと考えられる $\gamma_{R}$ の体積率と安定性および第 2 相形態の影響を調査した研究はほとんど見当たらない。著 者らはさきにこれらの $\gamma_{R}$ を利用して, TDP鋼の張出し性7) および伸びフランジ性 ${ }^{8-10)}$ が改善できることを報告した。 深絞り性も同様に，プレス成形性に影響を及ぼすと考えら れる $\gamma_{R}$ 制御（ $\gamma_{R}$ の体積率と安定性）によってさらに改善 できると予想される。

そこで本研究では, 炭素添加量の異なる数種類の TDP 鋼を用いて, 深絞り性に及ぼす $\gamma_{R}$ 特性の影響を詳細に検 討した。

\section{2. 実験方法}

供試鋼にはSi および Mnをそれぞれ $1.5 \mathrm{mass} \%$ 一定とし， 炭素量を $0.1 \sim 0.4$ mass\%の範囲で 0.1 mass\%ずつ変化させ

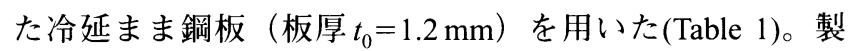
造条件は文献 8 に準じた。以後, これらの鋼をTDP1〜 TDP4 と呼ぶ。これらの鋼板に2台の塩浴炉を用いて, Fig. 1(a)に示す一律の熱処理, すなわち 2 相域 $\left(T_{\alpha+\gamma}\right)$ 焼なまし + オーステンパ処理を施し, フェライト $\left(\alpha_{f}\right)+$ ベイナイト $\left(\alpha_{b}\right)+\gamma_{R}$ の3相組織とした。ここで， $T_{\alpha+\gamma}$ には $780^{\circ} \mathrm{C}$ と $\gamma_{R}$ の初期体積率がほぼ最大となる温度を採用した4)。比較の ため，Si添加量の少ない同一の冷延まま鋼板を用い， MDPおよびBDPと呼ぶ。これらの鋼を熱処理により， $\alpha_{f}+$ マルテンサイト $\left(\alpha_{m}\right)$ 複合組織鋼（MDP鋼）および $\alpha_{f}+\alpha_{b}$ 複合組織鋼（BDP鋼）とした。MDP鋼には $400^{\circ} \mathrm{C} の$ 焼戻しを施した(Fig. 1(b), (c))。また， $\alpha_{f}$ を母相， $\alpha_{b}$ と $\gamma_{R}$ （ひずみ誘起変態した $\alpha_{m}$ も含む）およびそれらの混合相を 第2相と総称する。

Table 1. Chemical composition of steels used (mass\%).

\begin{tabular}{c|cccccc}
\hline Steel & $\mathrm{C}$ & $\mathrm{Si}$ & $\mathrm{Mn}$ & $\mathrm{P}$ & $\mathrm{S}$ & $\mathrm{Al}$ \\
\hline TDP1 & 0.10 & 1.49 & 1.50 & 0.015 & 0.0012 & 0.038 \\
TDP2 & 0.20 & 1.51 & 1.51 & 0.015 & 0.0011 & 0.040 \\
TDP3 & 0.29 & 1.46 & 1.50 & 0.014 & 0.0012 & 0.043 \\
TDP4 & 0.40 & 1.49 & 1.50 & 0.015 & 0.0012 & 0.045 \\
\hline MDP & 0.14 & 0.21 & 1.74 & 0.013 & 0.0030 & 0.037 \\
BDP & 0.14 & 0.21 & 1.74 & 0.013 & 0.0030 & 0.037 \\
\hline
\end{tabular}



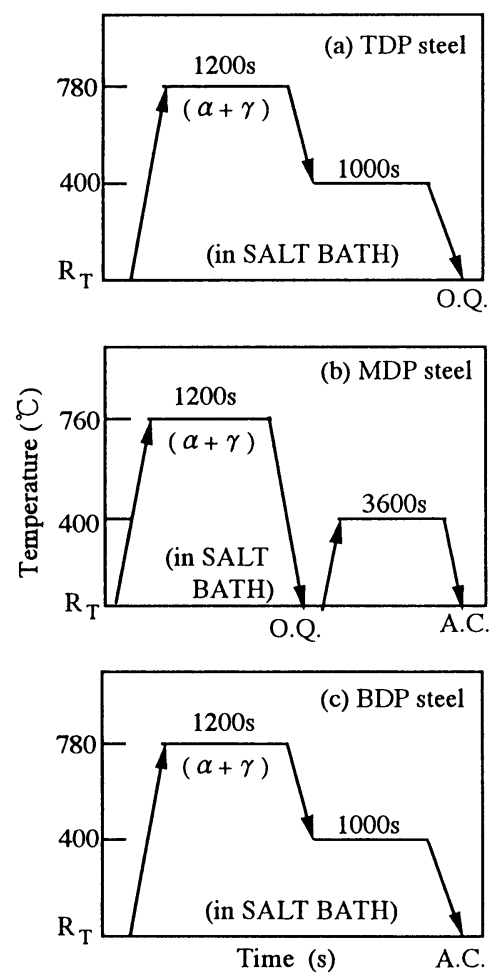

Fig. 1. Heat treatment diagram of TDP, MDP and BDP steels, in which "O.Q." and "A.C." represent quenching in oil and air cooling, respectively.

引張試験には圧延方向に平行に製作したJIS13B号引張 試験片を用い，インストロン型万能試験機によって，クロ スヘッド速度 $1 \mathrm{~mm} / \mathrm{min}$ (ひずみ速度 $2.8 \times 10^{-4} / \mathrm{s}$ ）で試験を 行った。

スウィフトカップ試験は， $1 \mathrm{~mm}$ 間隔にワイヤ放電加工 により作製した直径 $D_{0}=39 \sim 45 \mathrm{~mm}$ の円形ブランク試験片 を用い, 万能塑性加工機（インナ荷重 $784 \mathrm{kN}$, アウタ荷重 $490 \mathrm{kN})$ により行った。平頭パンチ直径 $d_{p} 20.64 \mathrm{~mm}$, ダイ ス内径 $24.40 \mathrm{~mm}$ で, 肩曲率半径はいずれも $4 \mathrm{~mm}$ の金型を 用いて行った(Fig. 2(a))。しわ押え力を $\mathrm{BHF}=0,10,50 \mathrm{kN}$ と 変化させ, 加工速度は約 $200 \mathrm{~mm} / \mathrm{min}$ とし, 試験片両面に は乾燥潤滑剤を塗布した。ここで, $\mathrm{BHF}=0 \mathrm{kN}$ は試験片よ り $0.2 \mathrm{~mm}$ 厚い板厚 $1.4 \mathrm{~mm}$ のスペーサーを試験片の 4 隅に 置き, BHF $=10 \mathrm{kN}$ で加圧した(Fig. 2(b))。深絞り性は限界 絞り比 $\left(L D R=D_{0} / d_{p}\right)$ で評価した。

$\gamma_{R}$ の体積率 $f_{\gamma}$ はX 線回折法により, Mo-K $\alpha$ 線の回折面 $(200)_{\alpha},(211)_{\alpha},(200)_{\alpha},(220)_{\gamma}$ および(311) $)_{\gamma}$ の ピーク法 ${ }^{17) を ~}$ 用いて測定した。また， $\gamma_{R}$ 中の初期炭素濃度 $C_{\gamma_{0}}$ (mass\%) は, $\mathrm{Cr}-\mathrm{K} \alpha$ 線の回折面(220) $)_{\gamma}$ から求めた格子定数 $a_{\gamma}(\mathrm{nm})$ を 次式 ${ }^{18)}$ に代入して計算した。なお，第 2 相体積率 $f$ は線分 法により求めた。

$C_{\gamma 0}=\left(a_{\gamma}-0.35467\right) / 4.67 \times 10^{-3}$

さらに，SEM観察およびビッカース硬さ測定（荷重 9.81N）も必要に応じ行った。

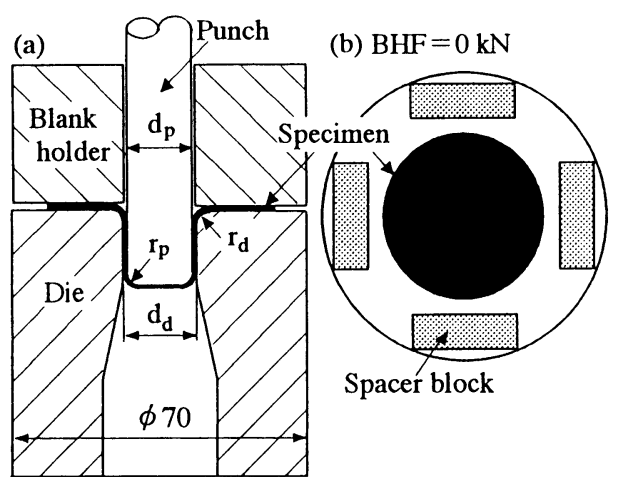

$\left(d_{p}=20.64 \mathrm{~mm}, r_{p}=4 \mathrm{~mm}, d_{d}=24.40 \mathrm{~mm}, r_{d}=4 \mathrm{~mm}\right)$

Fig. 2. Experimental apparatus for Swift cup test.

\section{3. 実験結果}

\section{$3 \cdot 1$ 組織と引張特性}

Fig. 3 にDP 鋼のミクロ組織の代表例を示す。(a,c)がレ ペラー腐食後の光顕写真, $(\mathrm{b}, \mathrm{d})$ が $3 \%$ ナイタール腐食後の SEM写真である。また, Fig. 4にTDP 鋼のTEM写真を示 す。ナイタール腐食後の SEM写真から， $\alpha_{b}$ と $\gamma_{R}$ からなる 第 2 相が母相の $\alpha_{f}$ 粒界に沿ってネットワーク状（連結状） に存在する $(\mathrm{b}, \mathrm{d})$ 。なお, レペラー腐食後の光顕写真から， TDP 鋼は $\alpha_{f}$ (灰色部)， $\alpha_{b}$ (黒色部)， $\gamma_{R}$ (白色部) で構成 される $(\mathrm{a}, \mathrm{c})$ 。また，Fig. 4 のような $\gamma_{R}$ 粒子の $\gamma_{R}$ 初期体積率 $f_{\gamma 0}$ は $0.05 \sim 0.17, \gamma_{R}$ 中の初期炭素濃度 $C_{\gamma 0}$ は 1.31 1.45 mass\%で炭素添加量の増加にともないそれぞれ高くなる (Table 2)。

Table 2 に供試鋼の引張特性を示す。TDP 鋼の引張強さ TSは 651 1103 MPa と広範囲にあり，いずれも大きな全伸 び $T E l$ と高い $n$ 值を有するが, $r$ 值は他の複合組織鋼と同様 1.0 以下と低い。

\section{$3 \cdot 2$ 深校り性}

Fig. 5 に各鋼の限界絞り比 $L D R$ と引張強さTSの関係を示 す。しわ押え力 $\mathrm{BHF}=0 \mathrm{kN}$ において，各 $\mathrm{TDP}$ 鋼の $L D R$ は 2.13 一定と良好である。一方, $\mathrm{BHF}=50 \mathrm{kN} に お い て ，$ 低 炭素添加量を有する TDP 鋼の LDRは低下する。また, $\gamma_{R}$

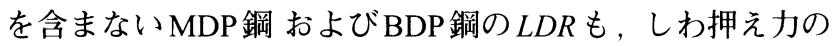
增加にともない低下する。

Fig. 6に深絞り性の指標として, 各鋼に扔ける引張強さ $T S$ と限界絞り比 $L D R$ の積, すなわち強度 - 深絞り性バラ ンス $T S \times L D R$ の比較を示す。 $\mathrm{BHF}=0$ と $50 \mathrm{kN}$ において， 炭素添加量の多い TDP 鋼ほど従来の MDP 鋼およびBDP鋼 に比較して優れた $T S \times L D R$ を有する。また，TS $\times L D R$ に対 して鋼種間の差は大きく現れる。TDP2 TDP4鋼の $T S \times L D R$ は, 強度-延性バランス $T S \times T E l$ と同様に極めて 高いことがわかる( $25 \mathrm{GPa} \%$ 以上，Table 2$)$ 。なお，深絞り 性と $n$ 值, $r$ 值および絞り $R A$ との相関はとくに認められな かった。 

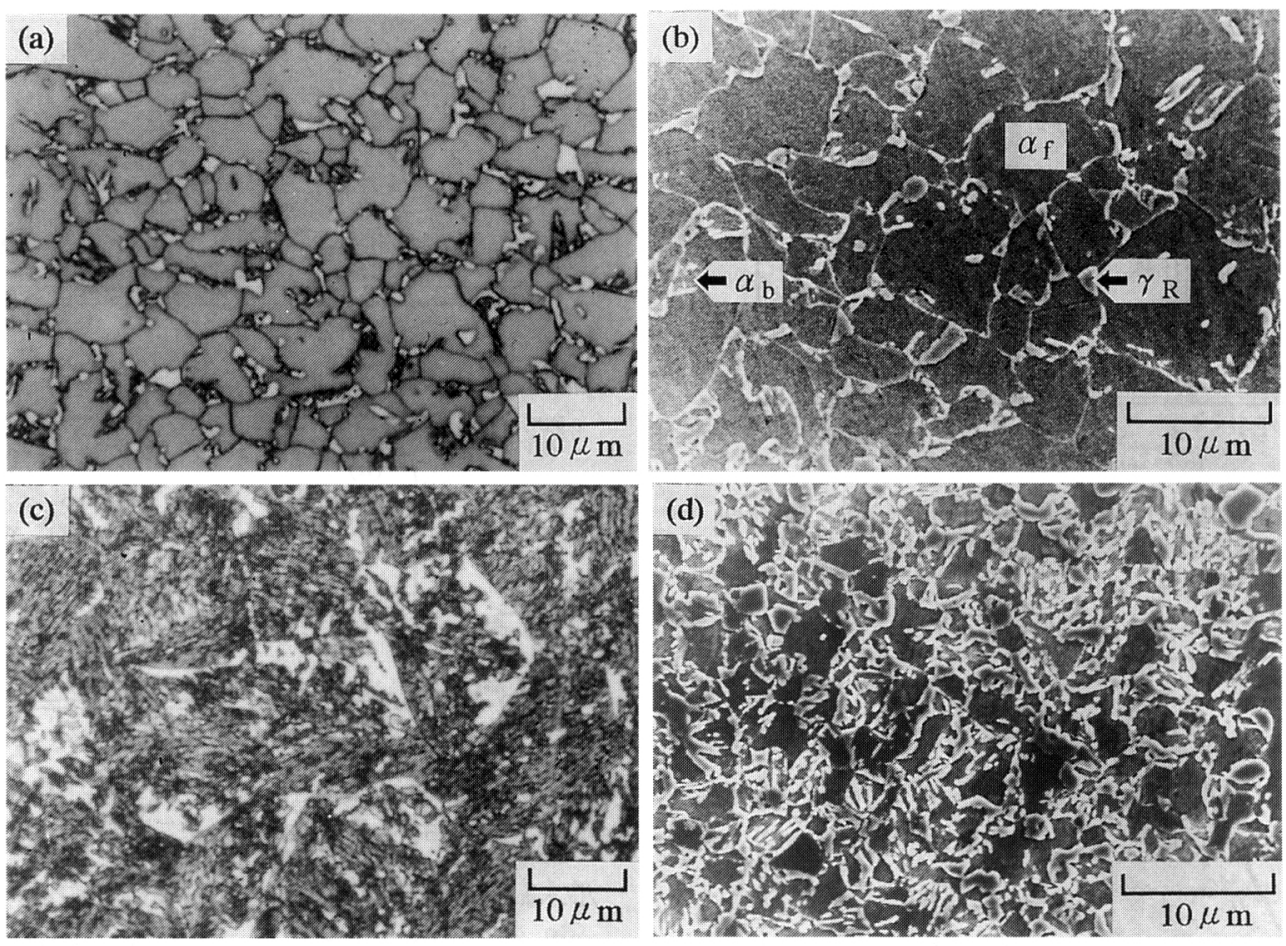

Fig. 3. Optical and scanning electron micrographs of (a and b) TDP1 and (c and d) TDP4 steels, in which white phases represent retained austenite and " $\alpha_{f}$ ", " $\alpha_{b}$ " and " $\gamma_{R}$ " are ferrite matrix, bainite and retained austenite, respectively.

Table 2. Retained austenite characteristics and tensile properties.

\begin{tabular}{l|c|c|c|c|c|c|c|c|c|c|c|c}
\hline Steel & $f$ & $f_{\gamma 0}$ & $\begin{array}{c}C_{\gamma 0} \\
(\mathrm{mass} \%)\end{array}$ & $\begin{array}{c}Y S \\
(\mathrm{MPa})\end{array}$ & $\begin{array}{c}T S \\
(\mathrm{MPa})\end{array}$ & $\begin{array}{c}U E l \\
(\%)\end{array}$ & $\begin{array}{c}T E l \\
(\%)\end{array}$ & $\begin{array}{c}T S \times T E l \\
(\mathrm{GPa} \%)\end{array}$ & $\begin{array}{c}R A \\
(\%)\end{array}$ & $H V_{0}$ & $n$ & $r$ \\
\hline TDP1 & 0.199 & 0.049 & 1.31 & 429 & 651 & 27.8 & 37.2 & 24.2 & 49.2 & 208 & 0.25 & 0.89 \\
TDP2 & 0.353 & 0.090 & 1.38 & 526 & 825 & 31.7 & 36.0 & 29.7 & 44.0 & $\mathbf{2 5 2}$ & 0.22 & 0.72 \\
TDP3 & 0.441 & 0.132 & 1.41 & 562 & 895 & 28.6 & 32.2 & 28.8 & 41.8 & 275 & 0.22 & 0.97 \\
TDP4 & 0.551 & 0.170 & 1.45 & 728 & 1103 & 29.2 & 32.8 & 36.2 & 41.8 & 299 & 0.21 & 0.90 \\
\hline MDP & 0.271 & - & - & 593 & 783 & 8.3 & 13.1 & 10.3 & 44.5 & 270 & 0.08 & 0.80 \\
BDP & 0.285 & - & - & 550 & 693 & 10.9 & 17.7 & 12.3 & 59.0 & 222 & 0.11 & 0.91 \\
\hline
\end{tabular}

$f$. volume fraction of second phase, $f_{\gamma 0}$ : volume fraction of retained austenite, $C_{\gamma 0}$ : carbon concentration in retained austenite, $Y S: 0.2 \%$ proof stress or yield stress, $T S$ : tensile strength, $U E l$ : uniform elongation, $T E l$ : total elongation, $T S \times T E l$ : strength -ductility balance, $R A$ : reduction of area, $H V_{0}$ : initial Vickers hardness, $n$ : work hardening exponent $(\varepsilon=5-15 \%)$ and $r$ : $r$-value $(\varepsilon=10 \%)$.

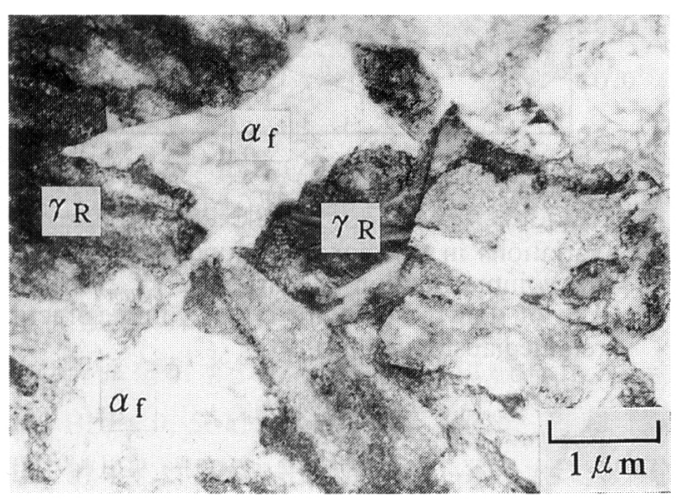

Fig. 4. Transmission electron micrograph of TDP2 steel, in which " $\alpha_{f}$ " and " $\gamma_{R}$ " are ferrite and retained austenite, respectively.

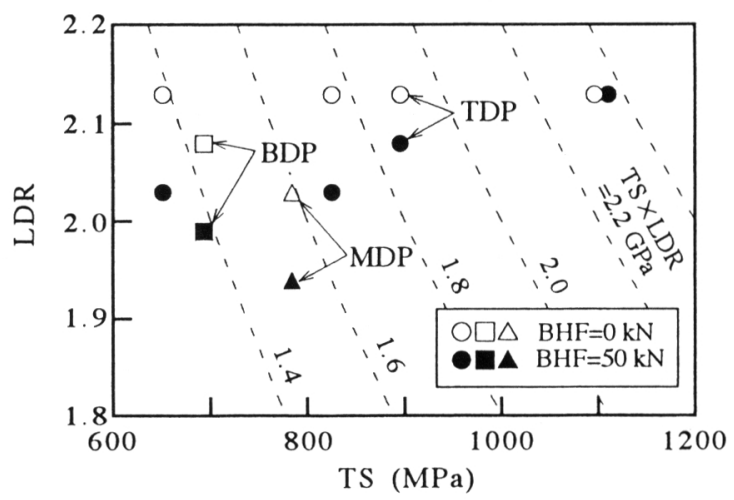

Fig. 5. Comparison of limiting drawing ratio $(L D R)$ of TDP, MDP and BDP steels as a function of tensile strength $(T S)$. 


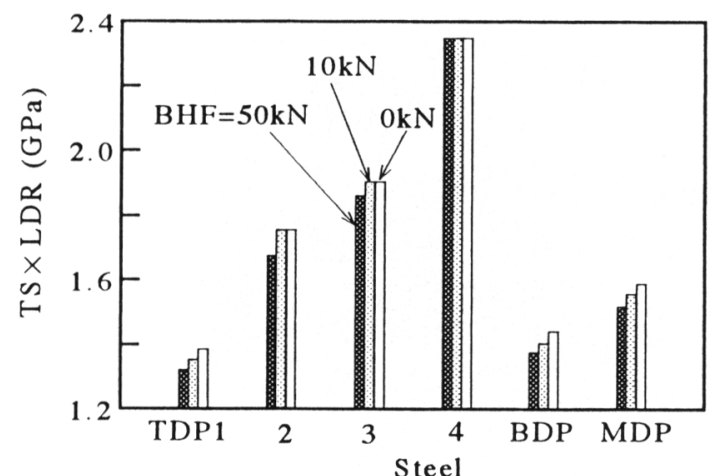

Fig. 6. Comparison of strength-deep drawability balance $(T S \times L D R)$ of TDP, MDP and BDP steels.

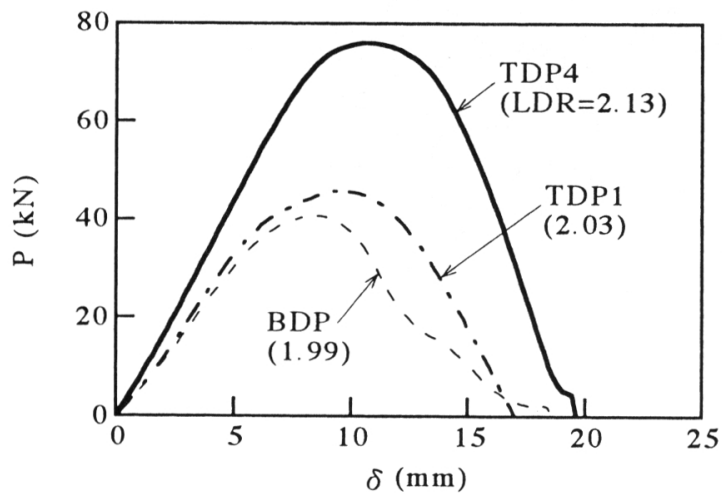

Fig. 7. Punch force $(P)$ vs. punch stroke $(\delta)$ for deep drawing at $\mathrm{BHF}$ of $50 \mathrm{kN}$.

Fig. 7 に深絞り試験の絞り力 $P$-ストローク $\delta$ 曲線を示

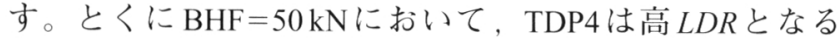
ことより, 高い最大絞り力 $P_{\max }$ と大きなパンチストローク を示す。

\section{$3 \cdot 3$ スウィフトカップのひずみ分布とひずみ誘起変態挙} 動

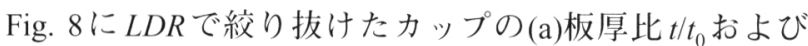
(b)硬さ比 $H V / H V_{0}$ における中心からの分布を示す $(\mathrm{BHF}=$ $10 \mathrm{kN})$ 。眓中，横軸の番号は，カップ断面の番号に対応す る。ここで， $t_{0}, t$ はそれぞれ初期板厚，成形後の板厚を， また $H V_{0}, H V$ はそれぞれ初期ビッカース硬さ(Table 2), 成形 後の硬さである。スウィフトカップ試験において，絞り成 形品の破断位置は各供試鋼ともすべてパンチ肩部で破断し た。板厚比はパンチ底で一様に薄くなり，パンチ肩部（4 番）で最小となる。また，TDP鋼においてパンチ肩部の カップ壁の硬さの増加が顕著に現れる。このパンチ肩部の 硬さは板厚比 $100 \%$ 超の縮みフランジ変形部（9番）の硬 さと同程度まで硬化している。

Fig. 9 に最大絞り力 $P_{\text {max }}$ およびひずみ誘起マルテンサイ 卜変態量 $f_{\alpha m}$ と $\gamma_{R}$ の初期体積率 $f_{\gamma 0}$ の関係を示す。ここで, $f_{\alpha m}$ は一つのひずみ量の指標として, カップ底部から採取 し，X線回折による $\gamma_{R}$ 量 $f_{\gamma}$ から求めた。本来であれば，板 材の深絞り変形に扎いては板面内の 2 軸応力による変形が
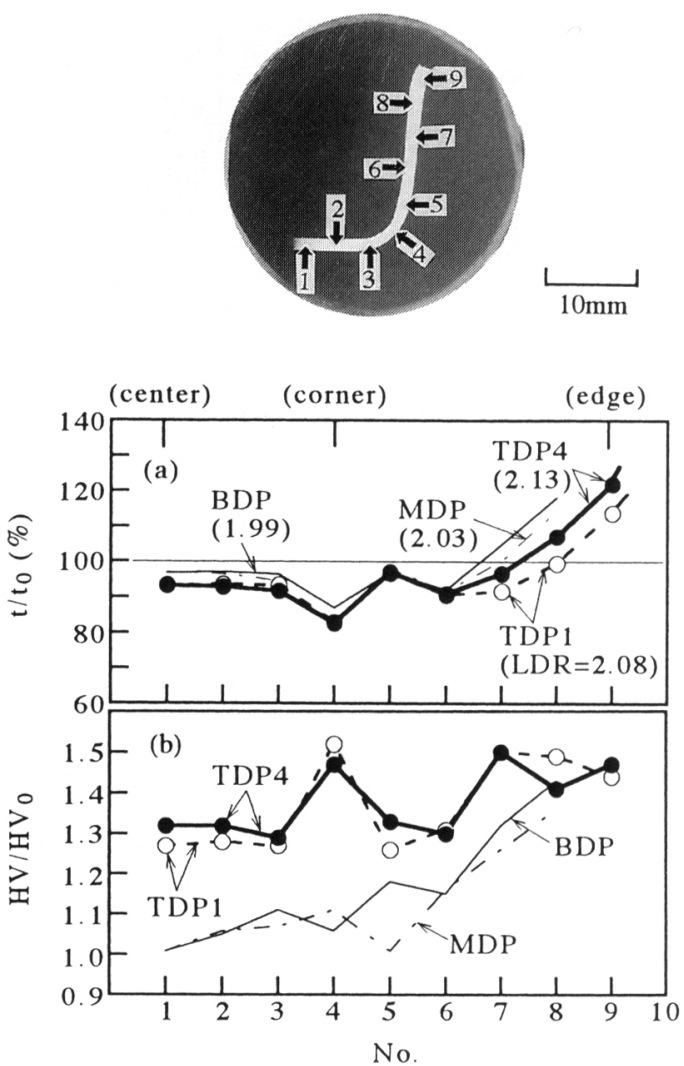

Fig. 8. Variations in (a) thickness ratio $\left(t / t_{0}\right)$ and (b) Vickers hardness ratio $\left(H V / H V_{0}\right)$ at the cross section of drawn cups $(\mathrm{BHF}=10 \mathrm{kN})$

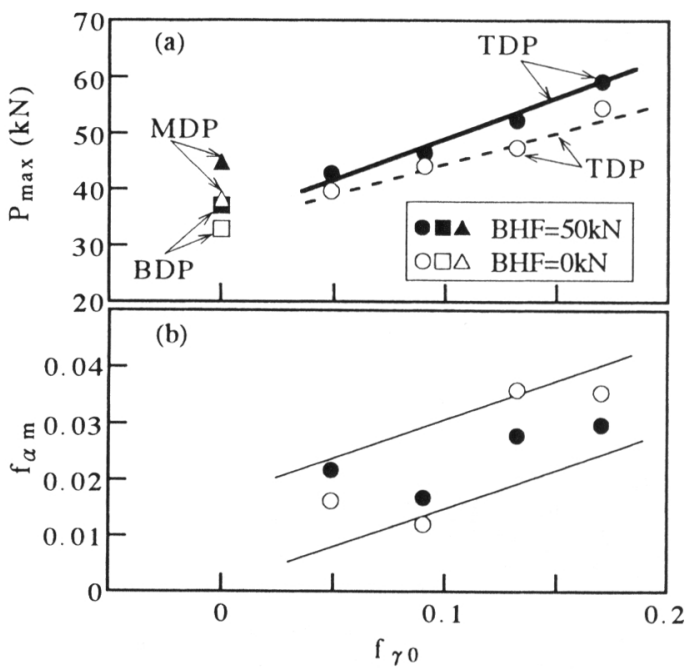

Fig. 9. Variations in (a) maximun punch force $(P)$ and (b) volume fraction of martensite $\left(f_{\alpha m}\right)$ in flat-bottom of drawn cups with initial volume fraction of retained austenite $\left(f_{\gamma_{0}}\right)$.

支配的であると考え, 縮みフランジ変形, 単軸引張変形, 平面ひずみ引張変形, 等 2 軸引張変形の各変形に対する $\gamma_{R}$ の安定性を調べる ${ }^{12)}$ ことが望ましい。絞り比 $D R=1.89$ に おいて，しわ押え力の有無にかかわらず， $f_{\gamma_{0}}$ の多い TDP 鋼ほど $P_{\max }$ を上昇させ,$f_{\alpha m}$ も多い傾向にあることがわか る。また，しわ押え力の上昇は各供試鋼とも $P_{\max }$ を上昇さ 


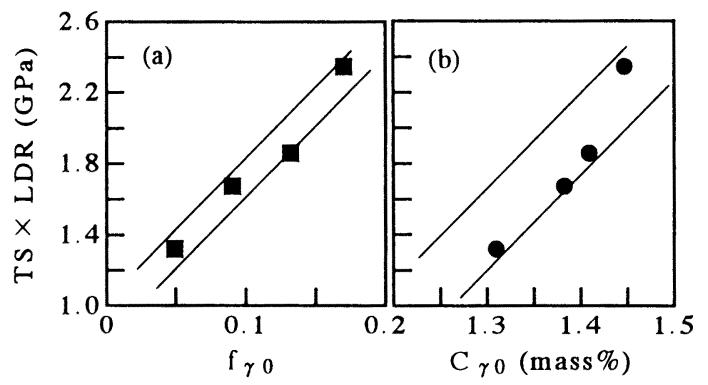

Fig. 10. Variation in strength-deep drawability balance $(T S \times L D R)$ as a function of $f_{\gamma 0}$ and $C_{\gamma 0}$ in TDP steels.

せる。

\section{4 深校り性と $\gamma_{R}$ 特性の関係}

Fig.10に強度 - 深絞り性バランス $T S \times L D R$ と $\gamma_{R}$ 特性 $\left(f_{\gamma 0}, C_{\gamma 0}\right)$ との関係を示す $(\mathrm{BHF}=0 \sim 50 \mathrm{kN})$ 。それぞれ正の相 関が現れ，これらの相関にはしわ押え力の影響は現れない。 $\gamma_{R}$ を含むTDP鋼の深絞り性が優れる理由は, ひずみ誘起 変態によるひずみ集中の緩和の他 ${ }^{11)}$, 深絞り成形で流入抵 抗を支えるパンチ肩部でのマルテンサイト変態による強度 上昇(Fig. 8)と対応する ${ }^{14)}$ 。この結果は, より多量でかつよ り安定な $\gamma_{R}$ が深絞り性改善の支配的因子であることがわ かる。

\section{4. 考察}

\section{$4 \cdot 1$ 相当破断力}

一般に，深絞り成形は縮みフランジ部の変形抵抗に相当 する最大絞り力 $P_{\text {max }}$ とパンチ肩側壁部での破断力 $P_{c r}$ によ り決定されるので, 両者の比すなわち相当破断力 $P_{\text {max }} / P_{c r}$ によって支配され，この值が小さいほど深絞り性は向上す る $^{12)} 。 P_{c r}$ は(2)式で定義され, 破断耐力 $\sigma_{p}$ は(3)式 ${ }^{19)} に よ$ り推定できる。

$$
\begin{aligned}
& p_{c r}=\pi d_{p} t_{0} \sigma_{p} \ldots \ldots \ldots \ldots \ldots \ldots \ldots \ldots \ldots \ldots \ldots \ldots \ldots \ldots \ldots . . .
\end{aligned}
$$

ここで, $d_{p}$ はパンチ直径 $(20.64 \mathrm{~mm}), t_{0}$ は初期板厚,$r$ はラ ンクフォード值, $n$ は加工硬化指数およびTSは引張強さを 示す。

Fig.11に強度-深絞り性バランス $T S \times L D R$ と相当破断力 $P_{\max } / P_{\mathrm{cr}}$ の関係を示す。ここで, $P_{\max }$ は絞り比 $D R=1.89$ 一 定および $\mathrm{BHF}=0,50 \mathrm{kN}$ (Fig. 9(a))の值で， $P_{c r}$ は Table 2 か ら計算した。困より負の相関が認められ, 相当破断力の低 下にともない深絞り性は向上した。すなわち, 炭素添加量 の増加にともないTDP 鋼は優れた深絞り性を示した。ま た，しわ押え力により TDP鋼の相当破断力が大きくなり (約 0.05)，深絞り性は低下した。

Fig. 8において，各鋼とも破断危険部となるパンチ肩部

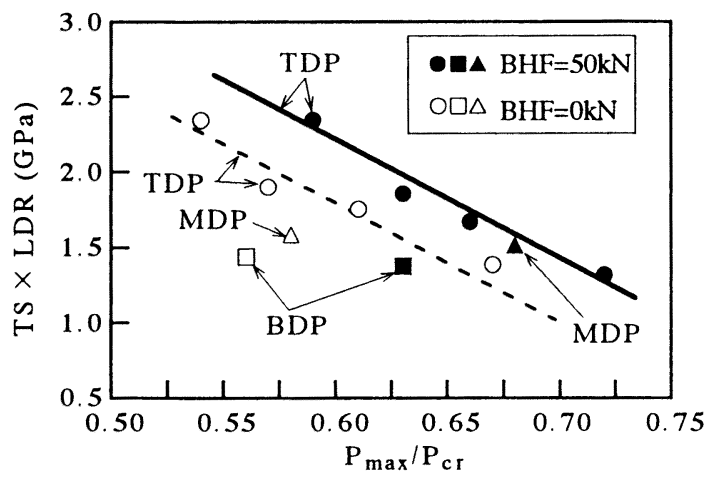

Fig. 11. Relation between strength-deep drawability balance $(T S \times L D R)$ and equivalent critical fracture force $\left(P_{\max } / P_{c r}\right)$.

（4番）で板厚ひずみが大きかった。この肩半径部の厚さ 方向の板厚ひずみ $\varepsilon_{t}=\ln \left(t_{0} / t\right)$ は $20 \%$ 程度の引張ひずみに相 当する。また, パンチ平底は $L D R$ が高い鋼ほど, 板厚比 が小さくなる傾向にある。一方, TDP鋼の硬さ比はパンチ 肩部で急激な硬化を示した。本TDP鋼のパンチ肩部での 板厚比は他の複合組織鋼と同程度であるので, ひずみ硬化 がとくに大きいとはいえない。このため, TDP鋼のパンチ 肩部では，ひずみ硬化に比べひずみ誘起変態(SIT)による 硬化が支配的であると考えられる。 $f_{\gamma 0}$ が異なるにもかか わらず硬さ比が変わらないのは， $\gamma_{R}$ がSITによって変態硬 化する割合が同程度であることを示唆している。このこと は, Fig. 9(b)のカップ平底でのひずみ誘起マルテンサイト 変態量 $f_{\alpha m}$ からも同様の傾向を示したことで裹付けられた。 以上より TDP鋼の深絞り性が優れる理由は, 深絞り成形 で流入抵抗を支えるパンチ肩部でのマルテンサイト変態に よる強度上昇と対応すると考えてよい。

\section{$4 \cdot 2$ 深絞り性に対する $\gamma_{R}$ の役割}

Fig.10にみるように, 強度-深絞り性バランスと $\gamma_{R}$ 特性 $\left(f_{\gamma 0}, C_{\gamma 0}\right)$ との関係は，それぞれ正の相関が現れた。また， これらの相関にはしわ押え力の影響は現れなかった。

著者ら ${ }^{14)}$ はさきに，0.2C-(1.0〜2.5) $\mathrm{Si}-(1.0 \sim 2.0) \mathrm{Mn}$ ， mass\%の TDP鋼において, 深絞り性は $f_{\gamma 0}\left(\gamma_{R}\right.$ の量）と正 の相関， $C_{\gamma_{0}}\left(\gamma_{R}\right.$ の質）と負の相関があることを報告した。 これは，炭素添加量が 0.2 mass\% 一定であることで，相対 的に $f_{\gamma 0}$ が高くなれば，逆に $C_{\gamma 0}$ は低くなることに起因する 点で, 本研究と $C_{\gamma 0}$ の位置付けは異なる。

そこで, Table 2 と Fig. 9(b)から Fig.12に第 2 相体積率と 炭素添加量の関係を示す。第 2 相体積率 $f$ と $f_{\gamma 0}$ の差がべイ ナイト体積率 $f_{\mathrm{b}}, f_{\gamma 0}$ と $f_{\alpha m}$ の差が未変態 $\gamma_{R}$ 量 $f_{\gamma}$ に相当すると 仮定すると， $f_{\alpha m}$ の割合は相対的に小さいことがわかる。 すなわち，Fig. 1(a)の同一の熱処理条件において，TDP鋼 は炭素添加量の増加にともない，第 2 相体積率も増加する ことで軟質なフェライト体積率が少なくなり，破断抵抗を 増加させる作用も併せ持つと考えられる。なお，パンチ底 で高炭素 TDP鋼ほど $f_{\gamma}$ が多く残存するのは， $\gamma_{R}$ の安定性 


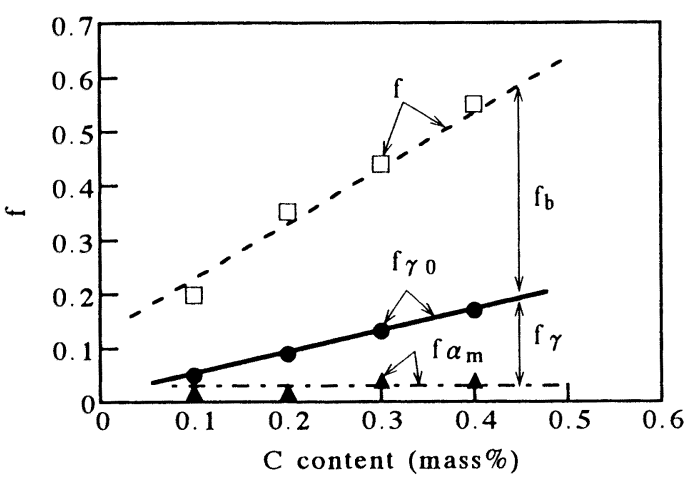

Fig. 12. Variation in volume fraction of second phase $(f)$ as a function of carbon content in TDP steels.

が関与していると考えてよいだろう。同様に，Matsumura $ら^{11)}$ は熱処理を変化させ, 多量でより安定な $\gamma_{R}$ が深絞り 性をよくすることを報告している。また，変態挙動と変形 様式の観点から，高炭素TDP鋼ほどパンチ肩部に比べフ ランジ部の変形抵抗が小さくなり，絞り力が低減された結 果，深絞り性が向上する ${ }^{12)}$ 考えられる。Fig.10より，よ り安定な $\gamma_{R}$ が $\gamma_{R}$ 量の増加によって深絞り性の指標である 強度一深絞り性バランスを改善できた。

一般に, 張出し性 ${ }^{7)}$, 伸びフランジ性 ${ }^{10)}$ の改善には, $\gamma_{R}$ の TRIP効果（SITによる応力集中の緩和とひずみ誘起 $\alpha_{m}$ の硬化）が重要な役割を果たす。深絞り性は，最も破断し やすいパンチ肩部の破断抵抗を高い值に保持しながら ${ }^{19)}$,

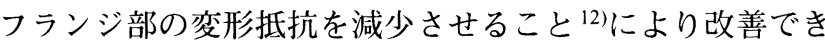
るので, $\gamma_{R}$ の TRIP効果の役割は相対的に小さく， $\alpha_{m}$ の強 化が重要な役割を果たすと考えてよいであろう。以上のこ とから, より多量でより安定な $\gamma_{R}$ を有する TDP鋼におい て, ひずみ誘起 $\alpha_{m}$ の強化がパンチ肩部の破断抵抗（半径 方向引張応力）を高めることと, 縮みフランジ変形抵抗 (円周方向圧縮応力）の減少との相互作用により改善され ることが示唆された。

\section{5. 結言}

TDP 鋼の深絞り性に及ぼす炭素添加量の影響を詳細に調 査した。主な結果は以下の通りである。

（1）本 TDP鋼は強度－延性バランス $T S \times T E l$ が極めて 高く，炭素添加量の多いTDP鋼ほど優れた強度一深絞り性 バランス $T S \times L D R$ を併せ持つ。
(2) 本 TDP 鋼の限界絞り比 $L D R$ はしわ押え力の上昇に 対して，炭素添加量の増加にともない良好であった。また その強度-深絞り性バランス $T S \times L D R$ は高炭素 TDP 鋼ほど 向上した。

（３）これは，より多量でかつ安定な $\gamma_{R}$ を有する TDP 鋼 において，ひずみ誘起 $\alpha_{m}$ がパンチ肩部の破断抵抗を高め たことと，縮みフランジ変形抵抗の减少との相互作用によ り改善された。

最後に，本研究を御支援いただきました（社）日本鉄鋼 協会・第 8 回鉄鋼研究振興助成【b】ならびに（財）天田 金属加工機械技術振興財団に対し，深く感謝の意を表する とともに，長野工業高等専門学校卒業研究生の丸山泰宏 氏・臼井敏雄氏に併せてお礼いたします。

\section{文献}

1 ) V.F.Zackay, E.R.Parker, D.Fahr and R.Busch: Trans. Am. Soc. Met., 60 (1967), 252

2 ) O.Matsumura, Y.Sakuma and H.Takechi: Trans. Iron Steel Inst. Jpn., 27 (1987), 570

3 ) K.Sugimoto, M.Kobayashi and S.Hashimoto: Metall. Trans. A, 23A (1992), 3085

4 ) K.Sugimoto, N.Usui, M.Kobayashi and S.Hashimoto: ISIJ Int., 32 (1992), 1311.

5 ) K.Sugimoto, M.Misu, M.Kobayashi and H.Shirasawa: ISIJ Int., 33 (1993), 775.

6 ) O.Matsumura, Y.Sakuma, Y.Ishii and J.Zhao: ISIJ Int., 32 (1992), 1110 .

7 ) K.Sugimoto, M.Kobayashi, A.Nagasaka and S.Hashimoto: ISIJ Int., 35 (1995), 1407.

8 ) A.Nagasaka, K.Sugimoto, M.Kobayashi and S.Hashimoto: Tetsu-toHagané, 83 (1997), 335.

9 ) A.Nagasaka, K.Sugimoto, M.Kobayashi and H.Shirasawa: Tetsu-toHagané, 84 (1998), 218.

10) K.Sugimoto, A.Nagasaka, M.Kobayashi and S.Hashimoto: ISIJ Int., 39 (1999), 56.

11) O.Matsumura, T.Ohue and T.Amaike: Tetsu-to-Hagané, 79 (1993), 209.

12) S.Hiwatashi, M.Takahashi, T.Katayama and M.Usuda: J. Jpn. Soc. Technol. Plast., 35 (1994), 1109.

13) A.Nagasaka, K.Sugimoto, M.Kobayashi and S.Hashimoto: Tetsu-toHagané, 85 (1999), 552.

14) A.Nagasaka, K.Sugimoto, M.Kobayashi, Y.Kobayashi and S.Hashimoto: Tetsu-to-Hagané, 85 (1999), 885.

15) Y.Ojima, Y.Shiroi, Y.Taniguchi and K.Kato: SAE Tech. Pap. Ser., \#980954, (1998), 39.

16）中川威雄：プレス成形難易ハンドブック第2版，日刊工業新聞 社, 東京, (1997), 403.

17) H.Maruyama: J. Jpn. Soc. Heat Treat., 17 (1977), 198.

18) 西山善次：マルテンサイト変態 基本編, 丸善, 東京, (1971), 13.

19) M.Usuda, Y.Ishii, S.Ujihara and T.Sakamoto: 36th Annual Meeting of J. Jpn. Soc. Technol. Plast., (1985), 317. 